\title{
RELEVANSI MATERI MATA PELAJARAN PEMELIHARAAN ENGINE SEPEDA MOTOR TERHADAP TUNTUTAN INDUSTRI
}

\author{
Susanty $^{1}$, Tatang Permana ${ }^{2}$, Sriyono $^{3}$ \\ Universitas Pendidikan Indonesia \\ Jl. Dr. Setiabudhi No. 229 Bandung 40154 \\ susanty9308@gmail.com
}

\begin{abstract}
ABSTRAK
Tujuan penelitian ini yaitu untuk mendeskripsikan relevansi materi pada mata pelajaran Pemeliharaan Engine Sepeda Motor dengan tuntutan industri, dan membuat pemetaan sekuen antara kedua kompetensi tersebut. Metode Penelitian ini menggunakan metode evaluasi congruence model. Instrumen yang digunakan pada penelitian ini berupa dokumentasi, wawancara dan angket. Penelitian ini dilaksanakan di SMKN 8 Bandung dan PT. Daya Adicipta Motora Cibeureum. Partisipan dalam penelitian ini yakni Kepala Diklat divisi Service, Workshop Head, dan instruktur di PT. Daya Adicipta Motor. Partisipan dari pihak SMKN 8 Bandung yakni Wakil Kepala Sekolah bidang Kurikulum serta Guru paket keahlian Teknik Sepeda Motor. Hasil dari relevansi antar kedua kompetensi tersebut adalah 70,3\%, hasil ini menunjukkan bahwa relevansi materi pemeliharaan engine sepeda motor di SMKN 8 Bandung termasuk kategori relevan. Pemetaan sekuen dari kedua kompetensi tersebut menghasilkan bahwa kompetensi mata pelajaran pemeliharaan engine sepeda motor sudah sesuai dengan tuntutan industri.
\end{abstract}

Kata kunci: relevansi materi, engine sepeda motor, tuntutan industri

\section{PENDAHULUAN}

Sekolah Menengah Kejuruan (SMK) merupakan lembaga pendidikan formal yang diharapkan mampu menjadi jembatan penghubung antara tenaga kerja (siswa) dengan lapangan kerja. Meskipun proses belajar mengajar di SMK tidak berbeda jauh dengan SMA, akan tetapi proses pembelajaran di SMK lebih dititikberatkan pada penerapan teori-teori yang telah diberikan melalui kegiatan praktikum (Arifin, 2011). Menurut UU Sistem Pendidikan Nasional pasal 15 disebutkan bahwa pendidikan Kejuruan merupakan pendidikan menengah yang mempersiapkan peserta didik untuk bekerja dalam bidang tertentu.

SMKN 8 Bandung adalah salah satu SMK unggulan di Bandung yang memiliki kompetensi khusus di bidang otomotif. Sekolah berupaya menghasilkan tamatan berkualitas, sebagai mekanik/tenaga kerja yang kompeten, wirausahawan yang sukses dan melanjutkan ke perguruan tinggi melalui pengembangan Iptek dan Imtaq. Lulusan dipersiapkan sebagai calon tenaga kerja yang memiliki kesiapan untuk memasuki dunia kerja. Keberadaan SMK dituntut untuk memenuhi kebutuhan masyarakat, yaitu kebutuhan tenaga kerja (Katharina, 2014). Sehingga peserta didik dituntut untuk memiliki keterampilan serta sikap profesional

\footnotetext{
${ }^{1}$ Mahasiswa Departemen Pendidikan Teknik Mesin FPTK UPI

2 Dosen Departemen Pendidikan Teknik Mesin FPTK UPI

${ }^{3}$ Dosen Departemen Pendidikan Teknik Mesin FPTK UPI
} 
dalam bidangnya. Sesuai dengan tujuan SMK yang menciptakan siswa atau lulusan: memasuki lapangan kerja dan mengembangkan sikap professional; mampu memilih karier, mampu berkompetensi dan mengembangkan diri; menjadi tenaga kerja tingkat menengah untuk mengisi kebutuhan dunia usaha/dunia industri saat ini dan masa yang akan datang, dan menjadi tenaga kerja yang produktif, adaptif dan kreatif (Dikmenjur, 2008).

Indikator yang mengatur ketercapaian tujuan dan visi dari SMK dengan melihat sejauh mana lulusan bisa bekerja, berwirausaha dan melanjutkan kuliah dengan baik. Lulusan SMKN 8 Bandung, khususnya peserta didik paket keahlian Teknik Sepeda Motor (TSM) yang bekerja di dunia usaha/dunia industri (DU/DI) dan instansi pemerintah adalah paling banyak dibandingkan dengan melanjutkan ke perguruan tinggi dan berwirausaha. Tidak semua yang bekerja di DU/DI dan instansi pemerintah ini bekerja di perusahaan otomotif.

Hasil wawancara dengan Wakil Kepala Sekolah bidang Kurikulum SMKN 8 Bandung bahwa keberadaan SMK dalam mempersiapkan tenaga kerja tingkat menengah yang terampil masih perlu ditingkatkan. Belum semua lulusan SMK dapat memenuhi tuntutan lapangan kerja sesuai dengan spesialisasinya. Hal ini karena adanya kesenjangan antara keterampilan yang dimiliki oleh lulusan SMK dengan keterampilan yang dibutuhkan di dunia kerja. Selain keterampilan, peserta didik SMK belum sepenuhnya memiliki kesiapan kerja, karena masih banyak lulusan SMK yang masih menganggur.

Hasil pengamatan pada saat observasi lapangan ditemukan bahwa tuntutan kurikulum tersebut tidak sepenuhnya dapat dilaksanakan. Hal tersebut karena berbagai keterbatasan sarana dan prasarana dalam pembelajaran serta kualitas SDM yang kurang mendukung. Tuntutan kurikulum yang tidak terpenuhi, akan berakibat tidak terpenuhinya kompetensi yang harus dikuasai oleh peserta didik pada mata pelajaran pemeliharaan engine sepeda motor.

Idealnya materi dari standar kompetensi pendidikan SMK Kurikulum 2013 dapat memenuhi kebutuhan industry. Kebutuhan yang masih banyak memerlukan tenaga terampil tingkat menengah. Lulusan SMK diharaapkan dapat mengisi pekerjaan tenaga pelaksana dalam dunia industri otomotif khususnya paket keahlian teknik sepeda motor. Kompetensi lulusannya mengacu pada kompetensi yang sangat dibutuhkan di industri. Kenyataannya, di lapangan banyak terdapat lulusan SMK paket keahlian teknik sepeda motor yang belum mampu untuk menyesuaikan diri dari tugas-tugas yang dibebankan kepadanya. Khususnya pada pihak industri dan asosiasi profesi sering mengeluh bahwa kualitas tenaga (lulusan) belum memenuhi tuntutan keahlian (kompetensi) yang diharapkan. Gejala mismatch seperti 
ini pada akhirnya melahirkan lulusan underqualifed. Keadaan seperti ini cukup lama terjadi, bahkan sampai saat ini.

Secara umum gambaran kesenjangan antara kompetensi lulusan SMK Paket Keahlian Teknik Sepeda Motor dengan kompetensi individu berdasarkan kebutuhan profesi di industry. Hal ini karena orientasi keduanya memang berbeda dan juga karena belum adanya perumusan serta pengimplementasian kurikulum pendidikan yang mampu secara utuh menjawab kebutuhan industri. Belum adanya pemetaan relevansi antara kompetensi di SMK dengan kompetensi yang ada di industri yang bias menjawab dari permasalahan tersebut. Salah satu alternatif jembatan kesenjangan tersebut adalah dengan lebih meningkatkan intensitas interaksi antara dunia pendidikan dan dunia industri melalui mekanisme kerja praktik atau internship (magang).

\section{METODE PENELITIAN}

Metode penelitian yang digunakan yaitu metode penelitian evaluasi. Metode ini untuk memperoleh gambaran mengenai efektivitas suatu program dalam mencapai tujuannya. Penelitian ini menggunakan desain evaluasi model congruence (persesuaian). Kegiatan evaluasi bertujuan untuk melihat sejauh mana tujuan dari suatu program telah dapat dicapai. Menurut model ini evaluasi tidak lain adalah usaha untuk memeriksa persesuaian antara tujuan yang diinginkan dan hasil yang dicapai. Pengukuran hasil penelitian model metode ini adalah sesuai atau tidak sesuainya kompetensi yang direlevansikan. Pertimbangan pemilihan metode ini berdasarkan pada tujuan dilakukannya penelitian ini sendiri, yakni untuk mengetahui gambaran relevansi materi pelajaran pemeliharaan engine sepeda motor terhadap tuntutan kompetensi yang ada di industri.

Penelitian ini dilaksanakan di SMK Negeri 8 Bandung dijalan Kliningan No.31, Turangga, Lengkong, Kota Bandung dan industri sepeda motor di Jawa Barat. Instrumen yang digunakan dalam penelitian ini, yaitu studi dokumentasi, wawancara, dan angket.

\section{HASIL PENELITIAN}

Hasil penelitian diperoleh adanya perbedaan kondisi di lingkungan sekolah dan di industri. Perbedaan tersebut sangat berpengaruh terhadap pencapaian kompetensi peserta didik. Perbedaannya dari segi teori, menekankan teori dasar dan penjelasan secara umum mengenai materi yang dibahas. Sedangkan di industri lebih spesifik dan mengutamakan troubleshooting dari materi yang diajarkan. Hal yang masih kurang dari SMK yaitu materi dari pemecahan masalah atau troubleshooting enginenya. Kondisi tersebut mengacu pada 
perbedaan dari segi praktik, dari segi sarana prasarana di sekolah belum memenuhi standar teknologi terbaru yang ada di industri.

Hasil data dan wawancara kompetensi lulusan SMK belum sesuai dengan kriteria yang ada di industri sepeda motor. Sekolah mengajarkan materi dan praktiknya secara umum, sedangkan pengerjaan yang ada di industri jauh lebih spesifik. Setiap industri sepeda motor mempunyai jobsheetnya masing-masing, disesuaikan dengan perkembangan teknologi yang semakin padat dan canggih. Sedangkan sebagai seorang teknisi haruslah memiliki semua kemampuan dalam memperbaiki semua jenis sepeda motor. Kelemahan yang ada di sekolah terletak pada segi materi praktik yang tidak sama dengan yang ada di industri. Contohnya sekolah masih menggunakan engine stand untuk yang menurut industri tidak kompeten untuk melakukan troubleshooting kerusakan sepeda motor.

Hasil dokumentasi dan wawancara relevansi antara kedua materi tersebut dalam kenyataan di lapangan masih kurang relevan. Banyak faktor yang menjadi permasalahan yang sering ditemukan. Diantaranya sarana dan prasarana pendukung yang masih kurang, mengakibatkan guru harus membagi dalam beberapa kelompok berdasarkan tugasnya masing-masing dan bergiliran. Dilihat dari teori ada dua foktor yang menjadi penyebabnya, yaitu SMK yang kekurangan guru yang berpengalaman industri dan kedua kelemahan fisik, mesin, alat dan bahan, serta kekurangan biaya operasional untuk penyelenggaraan praktik secara efektif.

Mata pelajaran pemeliharaan engine sepeda motor terdapat 20 kompetensi dasar yang terdiri dari tujuh materi pokok terdiri dari tujuh materi pokok itu antara lain: (1) mekanisme mesin; (2) sistem pengapian; (3) sistem pelumasan; (4) sistem pendinginan; (5) sistem bahan bakar; (6) mekanisme kopling; dan (7) mekanisme gear. Ketujuh materi pokok tersebut yang diuraikan 159 pokok bahasan selanjutnya direlevansikan pada materi kompetensi engine yang ada di industri khususnya materi dar industri.

Kompetensi engine di industri terdapat 15 kompetensi yang diuraikan 74 pokok bahasan. Diketahui bahwa materi pada mata pelajaran pemeliharaan engine sepeda motor hanya mempunyai 52 dari total 74 cakupan materi yang ada. Ada sebanyak 29,7\% materi yang tidak relevan dan sebesar 70,3\% materi yang relevan. Tingkat relevansi materi antara kedua kompetensi tersebut masuk dalam kategori relevan. Materi pemeliharaan engine sepeda motor hampir semua kompetensi memenuhi deskripsi unit. Keterpenuhan materi yang relevan pada mata pelajaran pemeliharaan engine sepeda motor pun menjadi berkurang dan jauh dari pencapaian relevansi dalam kategori yang sangat relevan. Ada beberapa materi yang tidak tersampaikan kepada peserta didik. Kompetensi yang tidak tersampaikan 
diantaranya pemeriksaan sistem pengaturan emisi, penggantian oli transmisi matik, dan pemeriksaan dan penggantian lifter tensioner.

Sudah mempunyai pemetaan materi mata pelajaran pemeliharaan engine sepeda motor, hanya saja belum maksimal. Pemetaan materi disana tidak sistematis, hanya melampirkan masukan-masukan materi dari industri. Pemberian materinya tidak berurutan. Sehingga mudah ditemukan materi yang ganda atau materi yang diulang-ulang.

\section{PEMBAHASAN}

Pencapaian kompetensi yang dimiliki peserta didik sebagai hasil belajar termasuk pada kategori yang kurang relevan dengan pencapaian kompetensi industri. Hasil analisis data, materi yang ada di deskripsi unit kompetensi engine sebenarnya sudah terpenuhi atau sudah tersampaikan semuanya ke peserta didik. Namun, tidak semua materi tersebut masuk dalam materi pemeliharaan engine sepeda motor. Sejalan dengan pemahaman guru pengampu mata pelajaran bahwa, materi itu pecahan-pecahan dari materi pembelajaran PMSM, dan relevansinya akan sangat besar. Hasilnya terlihat dari persentase angket yang disebarkan ke responden guru, ketua jurusan dan instruktur mengenai pencapaian kompetensi pada mata pelajaran pemeliharaan engine sepeda motor terhadap tuntutan industri masuk dalam kategori relevan (Jatmoko, 2013).

Hasil data yang diperoleh bahwa pencapaian kompetensi pada mata pelajaran pemeliharaan engine sepeda motor pada aspek kognitif mencapai level aplikasi. Tergambar dari silabus yang mana kegiatan praktik di lapangan jauh lebih banyak dibandingkan kegiatan teori di kelas. Kompetensi peserta didik/lulusan SMK dapat memenuhi kriteria kompetensi yang ada di industri. Pengetahuan yang dimiliki peserta didik pun bisa dilihat dari kemampuan peserta didik menjelaskan mengenai setiap aspek materi yang disampaikan selama pembelajaran praktik ataupun teori di kelas.

Tingkat relevansi dibagi menjadi tiga, yaitu sangat relevan, relevan marginal, dan tidak relevan (Meredith and Burgin, 2008). Materi pemeliharaan engine sepeda motor masuk dalam kategori sangat relevan terhadap materi yang ada di industri. Kurikulum 2013 SMKN 8 Bandung memang pada dasarnya sudah disesuaikan dengan standar kurikulum rekomendasi industri, tetapi dalam hal pelaksanaan ketercapaian kompetensi belum sepenuhnya mendukung terhadap kompetensi yang dibutuhkan di dunia kerja. Suatu ide atau rencana tertulis (berupa dokumen) belum memberikan dampak terhadap suatu perubahan sebelum ide itu sampai pada tingkat implementasi. Baik tidaknya suatu ide yang dituangkan 
dalam dokumen kurikulum tidak serta merta membuahkan hasil seperti rencana yang diharapkan, tetapi harus ditindaklanjuti dengan implementasi atau pelaksanaan lapangan.

Hasil pengolahan angket relevansi diproleh angka 70,3\%. Angka tersebut menunjukkan bahwa SMKN 8 Bandung masuk dalam kategori relevan terhadap kompetensi industri. Menurut hasil studi dokumentasi selisih nilai relevansi tersebut, karena pemecahan kompetensi yang menghasilkan ketidaksinambungan antar pelajaran. Contohnya pada kompetensi dasar $V$-matic system yang seharusnya ada pada mata pelajaran engine. Pada silabusnya sendiri tidak ada pembahasan $V$-matic system tetapi ada pada mata pelajaran chassis. Pemecahan materi tersebut juga mengakibatkan terjadi pembahasan materi yang ganda. Sehingga menjadikan kurang efisiennya waktu pembelajaran karena harus mengulang-ulang materi yang sama. Materi pemeliharaan engine sepeda motor sudah relevan dan memenuhi kebutuhan dunia industri. Relevansi materi pada mata pelajaran pemeliharaan engine sepeda motor terhadap tuntutan industri bisa menjadi sangat relevan apabila sering dilakukan penyamaan kompetensi secara terjadwal.

Pemetaan sekuen ini akan lebih memudahkan dalam pembacaan dan penafsiran dari hasil penelitian yang telah dilakukan, sehingga mampu menjadi rujukan dalam pengembangan kurikulum yang sistematis. Hasil wawancara diperoleh belum ada pemetaan materi antar mata pelajaran apalagi pemetaan antara sekolah dengan industri. Instruktur industri juga mengatakan hasil pemetaannya masih belum ada karena kita hanya memetakan materi yang ada di lingkungan bengkel saja (Lupiyadi, 2014).

Kesesuaian kemampuan pada aspek kognitif yang sesuai dengan apa yang diharapkan industri. Hal tersebut akan membekali peserta didik untuk bekerja menjadi teknisi di industri bidang teknik sepeda motor yang siap kerja dan kompeten (Hidayati, 2015). Pemetaan sekuen materi pada setiap mata pelajaran juga harus dilakukan agar mengurangi terjadinya penggandaan materi. Bisa ditambahkan dengan materi yang terbarukan dari industri. Materi pembelajaran pemeliharaan engine sepeda motor dapat lebih sistematis dalam penyampaian materi kepada peserta didik.

Kompetensi lulusan pada materi pelajaran pemeliharaan engine sepeda motor sudah sesuai untuk memenuhi kriteria yang ada di industry dan masuk dalam kategori tinggi. Implikasi kemampuan lulusan sudah setara dengan kompetensi mekanik yang ada di industri (Sanjaya. 2010). Relevansi materi pokok pada mata pelajaran pemeliharaan engine sepeda motor termasuk dalam kategori relevan. Implikasinya pada kepemilikan kompetensi dan kemudahan beradaptasi peserta didik dengan tuntutan kompetensi industri. Pemetaan sekuen materi antara kedua kompetensi sudah sesuai sehingga memudahkan untuk pencapaian 
kompetensi peserta didik karena tahapan pemateriannya sudah sesuai dengan yang ada di industri.

\section{KESIMPULAN}

Kesimpulan penelitiann ini, sebagai berikut: kompetensi lulusan SMK pada materi pemeliharaan engine sepeda motor sudah sesuai untuk memenuhi kriteria yang ada di Industri dan masuk dalam kategori tinggi. Relevansi materi pokok pada mata pelajaran pemeliharaan engine sepeda motor yang diterapkan termasuk dalam kategori relevan. Pemetaan sekuen materi antara kedua kompetensi (kompetensi pemeliharaan engine sepeda motor dan kompetensi di industri) termasuk dalam kategori sudah sesuai.

\section{REFERENSI}

Arifin, Z. (2011). Konsep dan Model Pengembangan Kurikulum. Bandung: PT. Remaja Rosdakarya Offset.

Hidayati, A. (2015). Relevansi Kompetensi Lulusan Sekolah Menengah Kejuruan dengan Kebutuhan Dunia Usaha dan Industri. Jurnal Fakultas Keguruan dan Ilmu Pendidikan Universitas Sebelas Maret Surakarta.

Jatmoko, D. (2013). Relevansi Kurikulum SMK Kompetensi Keahlian Teknik Kendaraan Ringan Terhadap Kebutuhan Dunia Industri Di Kabupaten Sleman. Jurnal Pendidikan Vokasi.

Katharina, V. (2014). Promoting Workforce Excellence: Formation and Relevance of Vocational Identity for Vocational Educational Training. Journal Empirical Research in Vocational Education and Training .

Lupiyadi, R. (2014). Manajemen Pemasaran Jasa Berbasis Kompetensi. Edisi ke-3. Jakarta: Salemba Empat.

Meredith, S., Burkle, M. (2008). Building Bidges Between University And Industri: Theory and practice. Journal Education and training. 50(3). pp.199-215.

Sanjaya. W. (2010). Strategi Pembelajaran Berorientasi Standar Proses Pendidikan. Jakarta: Kencana. 